\title{
EFFECTS OF COMPETITION AND WATER DEFICIENCY ON SUNFLOWER AND WEED GROWTH ${ }^{1}$
}

\author{
MURILO MEIRA SOARES ${ }^{2}$, CLÁUDIA DAIANNY MELO FREITAS ${ }^{2}$, FERNANDO SARMENTO DE OLIVEIRA ${ }^{2}$, \\ HÉLIDA CAMPOS DE MESQUITA ${ }^{2}$, TATIANE SEVERO SILVA ${ }^{2 *}$, DANIEL VALADÃO SILVA $^{2}$
}

\begin{abstract}
In the agricultural environment, the occurrence of biotic and abiotic stresses, such as weed interference and soil water deficit is common. However, little is known about the effects of the interaction of these stresses on the growth of cultivated crops and weed species. Thus, the objective of this study was to evaluate the effects of competition and water deficiency on the growth of sunflowers and weeds. The experiment was performed in a randomized block design with four replications. The treatments were arranged in a $5 \times 2$ factorial design, with the first factor corresponding to the competition arrangements between the species (sunflower + Waltheria indica; sunflower + Amaranthus spinosus; and sunflower, W. indica, and $A$. spinosus in monoculture without competition) and the second factor corresponding to water regimes (irrigated and water deficit). The water deficit regime was established when the sunflower plants had six expanded leaves (V6 stage) and was maintained until the rate of $\mathrm{CO}_{2}$ assimilation of the plants reached values close to zero (6 days), after which irrigation was resumed and maintained until 40 days after emergence, when the plants were collected and evaluated. The growth components evaluated were plant height, leaf area, dry leaf mass, dry stem mass, dry root mass, and total dry mass. Competition between plants decreased sunflower, $W$. indica, and $A$. spinosus growth. $W$. indica and $A$. spinosus aggravated the negative effects of water deficiency on sunflower growth. The water deficit regime did not affect the growth of $W$. indica. A. spinosus was more competitive with the sunflower than was $W$. indica.
\end{abstract}

Keywords: Helianthus annuus. Amaranthus spinosus. Waltheria indica. Water stress. Interference.

\section{EFEITOS DA COMPETIÇÃO E DO DÉFICIT HÍDRICO SOBRE O CRESCIMENTO DE GIRASSOL E PLANTAS DANINHAS}

RESUMO - No ambiente agrícola é comum a ocorrência de estresse de origem biótica e abiótica, como a interferência das plantas daninhas e o déficit hídrico no solo, respectivamente. Porém, pouco se conhece sobre os efeitos da interação desses estresses sobre o crescimento de espécies cultivadas e daninhas. Desta maneira, objetivou-se com este trabalho avaliar os efeitos da competição e do déficit hídrico sobre o crescimento de girassol e plantas daninhas. O experimento foi realizado em delineamento em blocos casualizados, com quatro repetições. Os tratamentos foram arranjados em fatorial $5 \times 2$, com o primeiro fator correspondente aos arranjos de competição entre as espécies (girassol + Waltheria indica; girassol + Amaranthus spinosus; girassol, W. indica e A. spinosus em monocultivo), e o segundo dos regimes hídricos (irrigado e déficit hídrico). $\mathrm{O}$ déficit hídrico foi estabelecido quando as plantas de girassol apresentavam seis folhas expandidas - estádio V6 e mantido até que a taxa de assimilação de $\mathrm{CO}_{2}$ das plantas alcançasse valores próximos à zero (6 dias), quando foi retomada a irrigação, sendo mantida até aos 40 dias, momento em que as plantas foram coletadas. Os componentes de crescimento avaliados foram: altura de planta, área foliar, massa seca de folha, caule, raiz e total. A competição entre plantas reduz o crescimento do girassol, $W$. indica e A. spinosus. As espécies $W$. indica e $A$. spinosus agravam os efeitos negativos do déficit hídrico sobre o crescimento do girassol. O déficit hídrico não afeta o crescimento da espécie $W$. indica. O A. spinosus é mais competitivo com o girassol do que a W. indica.

Palavras-chave: Helianthus annuus. Amaranthus spinosus. Waltheria indica. Estresse hídrico. Interferência.

\footnotetext{
${ }^{*}$ Corresponding author

${ }^{1}$ Received for publication in $07 / 11 / 2018$; accepted in 10/04/2018.

Paper extracted from the course conclusion monograph of the first author.

${ }^{2}$ Department of Agronomic and Forest Sciences, Universidade Federal Rural do Semi-Árido, Mossoró, RN, Brazil; murilomeirasoares@hotmail.com - ORCID: 0000-0002-8201-2384, claudiamelof@hotmail.com - ORCID: 0000-0001-5243-5071, fernandosarmentho@hotmail.com - ORCID: 0000-0002-4019-5899, helidamesquita.ifrn@gmail.com - ORCID: 0000-0003-0357-6841, tatiane.severosilva@gmail.com - ORCID: 0000-0002-3543-6811, daniel.valadao@ufersa.edu.br - ORCID: 0000-0003-0644-2849.
} 


\section{INTRODUCTION}

The sunflower (Helianthus annuus L.) is one of the most important oleaginous species worldwide, being cultivated in all continents (CASTRO; LEITE, 2018). Sunflower crops are mainly used to produce seed oil for human consumption and to produce biofuels (DANTAS et al., 2017). The average Brazilian yield of sunflower (average grain yield) is $1319.3 \mathrm{~kg} \mathrm{ha}^{-1}$, which is considered low when compared to other countries, such as the Ukraine with $2238.8 \mathrm{~kg} \mathrm{ha}^{-1}$ (FAO, 2016). Among the factors contributing to this result are biotic and abiotic stresses, such as weed interference and soil water deficiency.

The occurrence of water deficiency is an increasingly frequent situation in rainfed crops in Brazil and may lead to reduced growth and crop yield losses (RAHMATI et al., 2018). The sunflower is a species that is considered tolerant to temporary soil water deficit (AHMAD et al., 2014); however, factors that increase the severity of droughts may reduce the ability of this species to tolerate stressful conditions. For example, an increase in atmospheric temperature was found to intensify the negative effects of water deficiency on sorghum plants, a species recognized for its great adaptability to hot regions (LOBELL et al., 2015), and sunflower varieties that are susceptible to drought (KILLI et al., 2017).

Weeds can also act as agents causing abiotic stresses related to the unavailability of essential growth resources, such as water, light, and nutrients. This interaction is known as competition (SILVA et al., 2013). Under field conditions, competition with weeds can reduce sunflower yields by up to $70 \%$ (ALVES et al., 2013).

The intensity of the negative effects of competition from weeds with cultivated crops depends on several factors, such as the competitive characteristics of the crop and weed species. The sunflower is considered a crop with a good competitive capacity, due to its higher stature; however, it is sensitive to competition during the first weeks after planting, with a total prevention period of interference ranging from 26 to 43 days (ELEZOVIC et al., 2012; ALVES et al., 2013; SILVA et al., 2013). Weed species such as boater bush (Waltheria indica L.) and spiny pigweed (Amaranthus spinosus L.) are frequently found in agroecosystems and are considered good competitors because they can tolerate water stress conditions and have a $\mathrm{C} 4$ fixation mechanism, respectively (LIMA et al., 2016; ASSAD et al., 2017; OLIVEIRA et al., 2018).

Therefore, the hypothesis was proposed that competition between weeds and cultivated crops can aggravate the negative effects caused by water deficiency, with serious implications for the growth components of the species. Thus, the objective of the present study was to evaluate the effects of competition and water deficiency on the growth of sunflower plants and $A$. spinosus and $W$. indica weeds.

\section{MATERIAL AND METHODS}

The experiment was performed in a greenhouse from April to June 2016. The experimental unit corresponded to a plastic vessel with a volume capacity of $8.5 \mathrm{dm}^{3}(24 \times 23 \mathrm{~cm}$ in diameter and height, respectively), filled with samples of a Cambisol collected from the $0-20 \mathrm{~cm}$ soil layer (EMBRAPA, 2013). After collection, analysis of physical and chemical attributes was performed, which revealed the following characteristics: $\mathrm{pH}$ (water) $=7.2$; organic matter $=$ $8.10 \mathrm{~g} \mathrm{~kg}^{-1} ; \mathrm{P}, \mathrm{K}$, and $\mathrm{Na}=2.2,434.6$, and $49.3 \mathrm{mg}$ $\mathrm{dm}^{-3}$, respectively; $\mathrm{Ca}, \mathrm{Mg}, \mathrm{Al}, \mathrm{H}+\mathrm{Al}$ and effective $\mathrm{CEC}=11.30,2.10,0.00,0.00$, and $14.73 \mathrm{cmol}_{\mathrm{c}} \mathrm{dm}^{-3}$, respectively; sand, silt, and clay $=0.57,0.10$, and $0.33 \mathrm{~kg} \mathrm{~kg}^{-1}$, respectively; and sandy clay loam texture. The fertilization of the experiment followed the recommendations for the use of correctives and fertilizers in Minas Gerais (RIBEIRO; GUIMARÃES; ALVAREZ, 1999), applying 72.9, 52.1 , and $25.86 \mathrm{mg} \mathrm{dm}^{-3}$ of monoammonium phosphate, urea, and potassium chloride, as a source of phosphorus, nitrogen, and potassium, respectively.

The experimental design was a randomized block design with four replications. The treatments were arranged in a $5 \times 2$ factorial design, with the first factor corresponding to the arrangements between the species (sunflower $+W$. indica, sunflower $+A$. spinosus, and sunflower, $W$. indica, and $A$. spinosus in monoculture without competition) and the second factor corresponding to the water regimes (irrigated and water deficit).

The sunflower hybrid used was Aguará 06, which was obtained commercially from the Atlântica Sementes Company. The seeds of the $W$. indica and $A$. spinosus weeds were collected from agricultural fields in the region. The seeds of these species were submitted to preliminary testing of germination and emergence with the aim to establish the sowing period of each species so that the emergence of these species was simultaneous with that of the crop.

The sowing of the sunflower and weeds was performed at the center and border of each experimental unit, respectively. The plants were thinned five days after emergence, with only one plant of each species remaining in the vessel.

Irrigation was performed daily with the aim to maintain the soil at $70 \%$ of field capacity. The water volumes applied were obtained from the difference between the mass of the vessel in its previously determined field capacity and the mass of the vessel on the day of irrigation, performed daily, following the methodology described by Sousa et al. (2015). 
The water deficit regime was established once the sunflower plants had six expanded leaves (V6 stage), a period during which competition with weeds can reduce the final yield of the crop, and thus increase production costs (ALVES et al., 2013). The duration of the water deficit regime was maintained until the $\mathrm{CO}_{2}$ assimilation rate of the sunflower plants reached values close to zero. The $\mathrm{CO}_{2}$ assimilation rate was measured using an infrared gas analyzer (IRGA, portable model LI-6400, LI-COR Biosciences) based on the methodology described by Lima et al. (2016). The period required for the $\mathrm{CO}_{2}$ assimilation rate to reach zero was 6 days. Then, irrigation was restored and the humidity maintained close to $70 \%$ of field capacity. At 40 days after emergence, by which time the photosynthetic rate of the plants submitted to the water deficit regime equaled those of the irrigated plants, the plants were collected and evaluated.

The growth components evaluated were plant height $(\mathrm{PH})$, which was determined using a graduated ruler and measured from the base of the lap to the insertion of the last fully expanded leaf and leaf area (LA), which was obtained with the corrected disk method (SOUZA et al., 2012). The sunflower plants, and $W$. indica and A. spinosus weeds were fractionated into leaves, stems, and roots, and were then separately packaged in paper bags and placed in a forced circulation oven at $65 \pm$ $1{ }^{\circ} \mathrm{C}$ until reaching a constant mass. Then, each part of the plant was weighed on an analytical balance to obtain the dry leaf mass (DLM), dry stem mass (DSM), dry root mass (DRM), and total dry mass (TDM).

The data were submitted to analysis of variance using the $F$ test $(p \leq 0.05)$ and, when significant, the averages were compared by Tukey's test at the 5\% probability level using the statistical software program SISVAR (FERREIRA, 2011).

\section{RESULTS AND DISCUSSION}

\section{Effects of competition and water deficiency on sunflower growth}

From the analysis of variance results, interaction was observed among the competition arrangements between the species and water regimes for $\mathrm{PH}$ and DRM. There was an isolated effect between the competition factors and water regimes for LA, DLM, and TDM, whereas for DSM there was only an isolated effect for the water regimes factor.

The water deficit regime affected the growth rate of sunflower plants when cultivated alone and in competition with $A$. spinosus, which resulted in plants with lower heights (Figure 1A). This could be caused by the stress related to water deficiency, which is characterized by a reduction in soil water content and, consequently, a reduction in leaf water potential, stomatal closure, loss of turgescence, and consequently there is a decrease and/or interruption in cell growth (JALEEL et al., 2009). For example, in Abelmoschus esculentus (okra) plants, the reduction in height under the water deficit regime might be associated with a decline in cell growth and increase in leaf senescence (BHATT; SRINIVASA RAO, 2005).

Under irrigated conditions, competition with weeds did not affect the sunflower $\mathrm{PH}$, in relation to the free treatment of coexistence (Figure 1A). Thus, the presence of weeds did not cause interference to the sunflower, e.g., light competition (shading) was not enough to change the shoot growth of the crop. $\mathrm{Lu}$ et al. (2016) evaluated the growth of $A$. retroflexus in soybean crops and did not observe any competition influence in $\mathrm{PH}$. Under water stress conditions in the present study, there was an interference effect only for $A$. spinosus, which intensified the effects of water restriction, with a severe reduction in sunflower $\mathrm{PH}$ compared to the isolated treatment (without the presence of weeds).

The plants under water deficit conditions had lower LA values than those in the irrigated treatment (Figure 1B). This reduction in LA might be related to reduction in the rate of expansion of young leaves, suspension of the production of new leaves, and the fall of green leaves. These stress-induced changes caused by water deficiency reduce LA and, consequently, loss of water via transpiration, promoting water savings (DÍAZ-LÓPEZ et al., 2012). Leaf abscission is mainly due to the synthesis of and sensitivity to ethylene (ABELES; MORGAN; SALTVEIT JR, 1992). Auxin and ethylene have an antagonistic relationship in the regulation of leaf abscission in many plant species, where the reduction of the auxin concentration in the leaf increases the production and sensitivity to ethylene (TAIZ et al., 2017). 

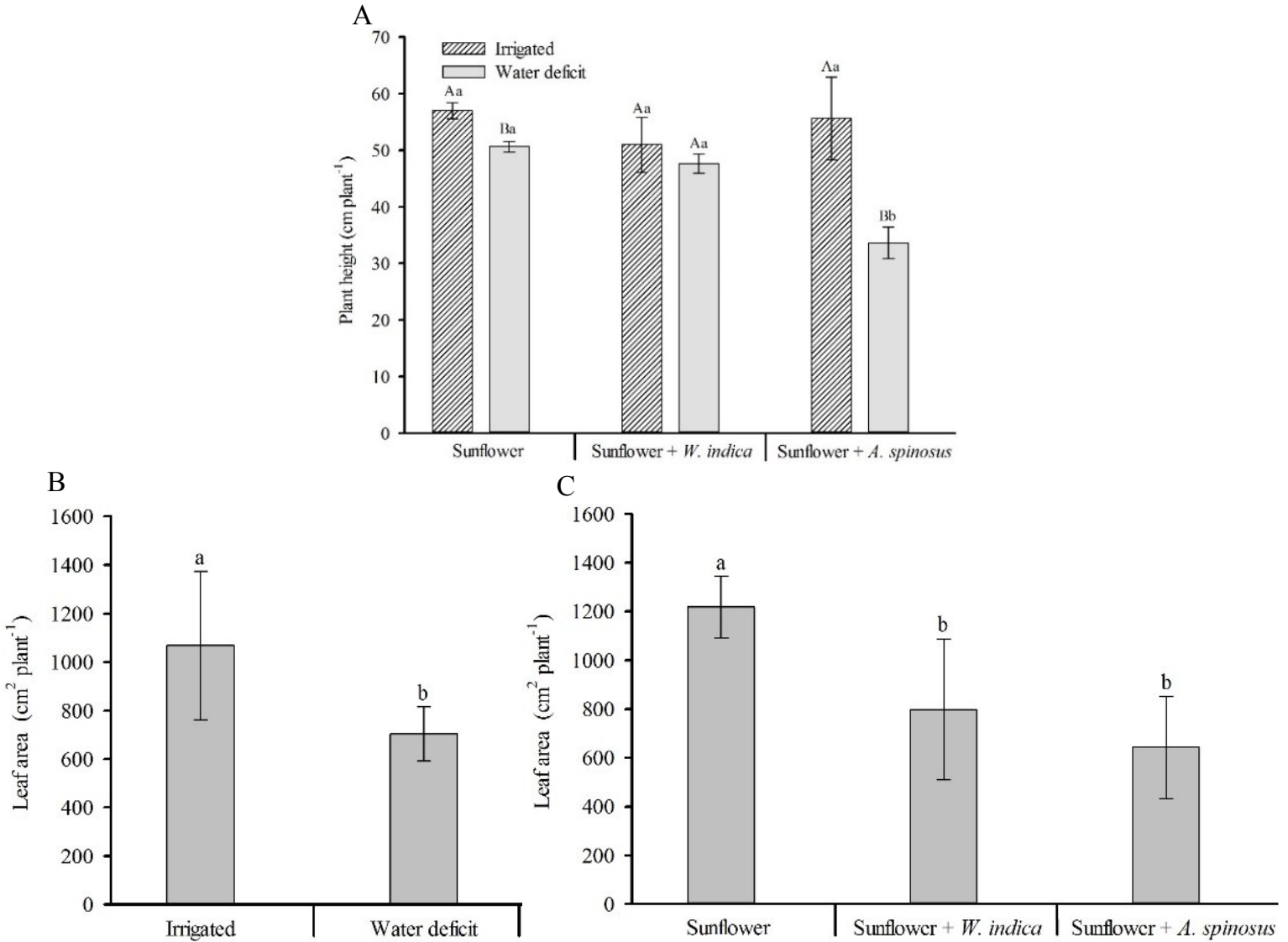

Figure 1. Plant height $(\mathrm{A})$ and leaf area $(\mathrm{B}, \mathrm{C})$ of sunflower plants as a function of water regimes and competition with Waltheria indica and Amaranthus spinosus. Figure 1A: means followed by the same lowercase letter (between the competition arrangements in each water regime) and upper case (between the water regimes within each competition arrangement) do not differ at the 5\% probability level by the Tukey's test. Figures $1 \mathrm{~B}$ and C: averages followed by the same letter do not differ at the $5 \%$ probability level by the Tukey's test. Error bars indicate mean confidence interval at $95 \%$ probability.

Regarding the effect of competition on FA, independently of the weed species, the competition gave lower values than those for the sunflower plants grown in isolation (Figure 1C). This occurred because, in general, weeds present a higher growth rate during the early stages, causing them to have an initial advantage, with such small competitive advantages during the onset of growth being converted into large differences in size, and thus the capacity to intercept light (CORRE-HELLOU et al., 2011). The sunflower, which is a slow initial developmental plant (shoot growth), was probably affected during the initial stage by weed interference, due to light competition that affected the LA of the crop (SILVA et al., 2013).
The water deficit regime reduced the DLM, DSM, DRM, and TDM of sunflower plants by $42.7 \%, 48.5 \%, 44.9 \%$, and $43.9 \%$, respectively, compared to the irrigated treatment (Figure 2). In general, during periods of water deficiency, available soil water is decreased and, to cope with this, plants tend to have greater stomatal regulation to minimize loss via sweating. Although this response to water deficiency helps to maintain adequate water potential of the plant, there is also a reduction in the absorption of $\mathrm{CO}_{2}$ and, consequently, reduction in the photosynthetic and respiration rates, which reduces dry mass production (URBAN; AARROUF; BIDEL, 2017). 

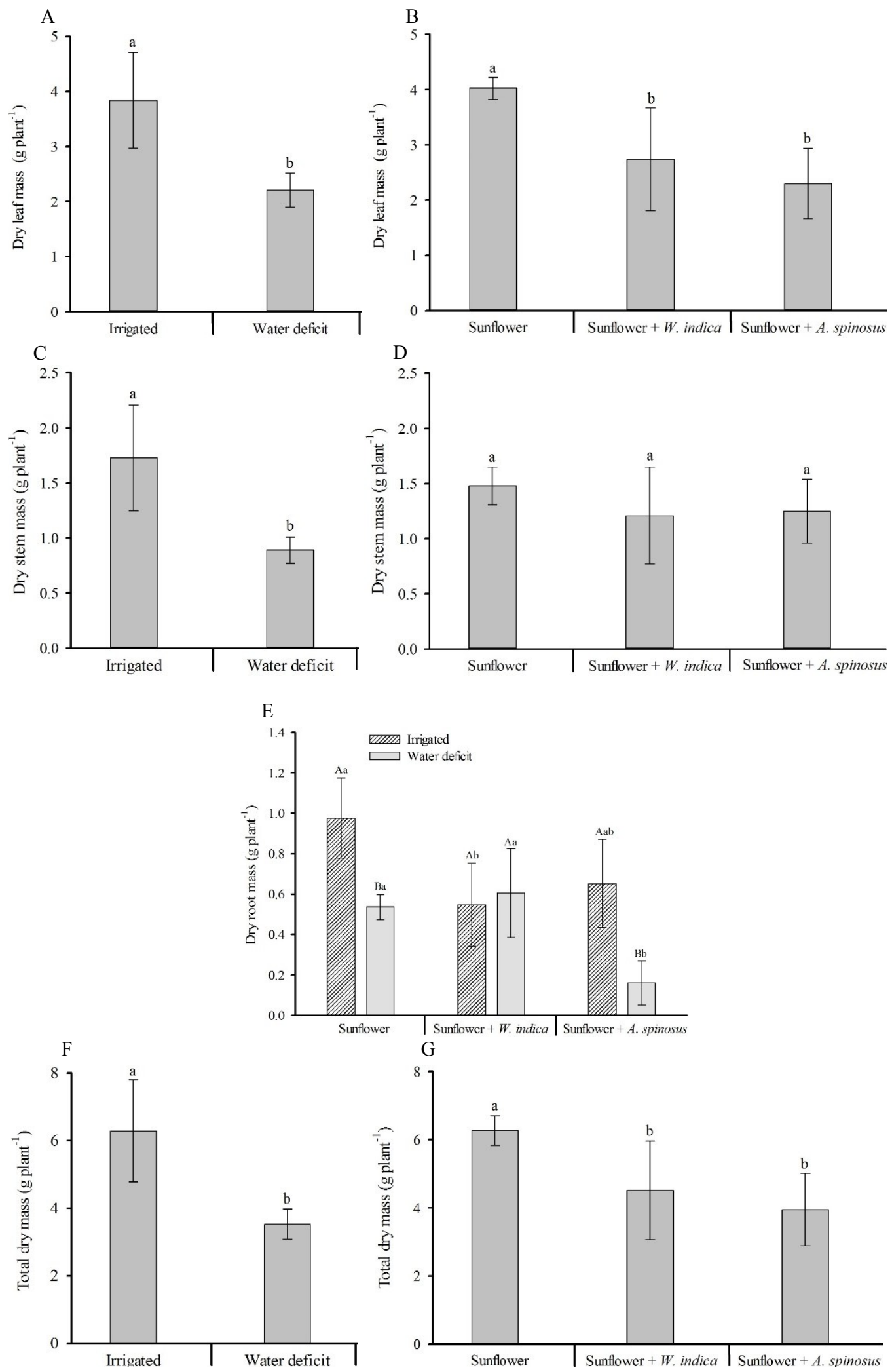

Figure 2. Dry leaf mass (A, B), dry stem mass (C, D), dry root mass (E), and total dry mass (F, G) of sunflower plants as a function of water regimes and competition with Waltheria indica and Amaranthus spinosus. Figure 2E: means followed by the same lowercase letter (between the competition arrangements in each water regime) and upper case (between the water regimes within each competition arrangement) do not differ at the $5 \%$ probability level by Tukey's test. Other figures: means followed by the same letter do not differ to the level of $5 \%$ of probability by Tukey's test. Error bars indicate the mean confidence interval at $95 \%$ probability. 
When analyzing the competition effect, independently of the species, the presence of weeds with sunflower plants resulted in lower DLM (Figure 2B) and TDM (Figure 2G) than that of the treatment without interference. The reduction of these growth variables is possibly a reflection of the species response when perceiving the change in light quality due to the presence of weeds (LAGE et al., 2017). The effects of this alteration in light quality is usually noticed in the growth components, such as branching, foliar and tiller senescence, alteration of the photoassimilates partition (GOMMERS et al., 2013), LA, lower density of tillers (SZYMEZAK et al., 2016), and dry mass production (DAN et al., 2010).

In contrast, for DSM, no competition effect was observed (Figure 2D). This behavior reflects the sunflower height not being affected even under competition with weeds. Many species develop escape responses to overcrowding, which include rapid elongation of stems and the elevation of leaves towards light (FRANKLIN, 2016).

For DRM (Figure 2E), a reduction was observed when in competition with $W$. indica under irrigated conditions. Similar to the present study, Almeida et al. (2015) found a smaller increment in DRM accumulation when the soybean competed with Urochloa brizantha and Bidens pilosa. It was verified that the competition from $A$. spinosus intensified the effects of the water restriction, with an even more severe reduction in DRM for the sunflower plants. A. spinosus has a pivotal root system (CHAUHAN; ABUGHO, 2013) and may have explored the same region as the sunflower

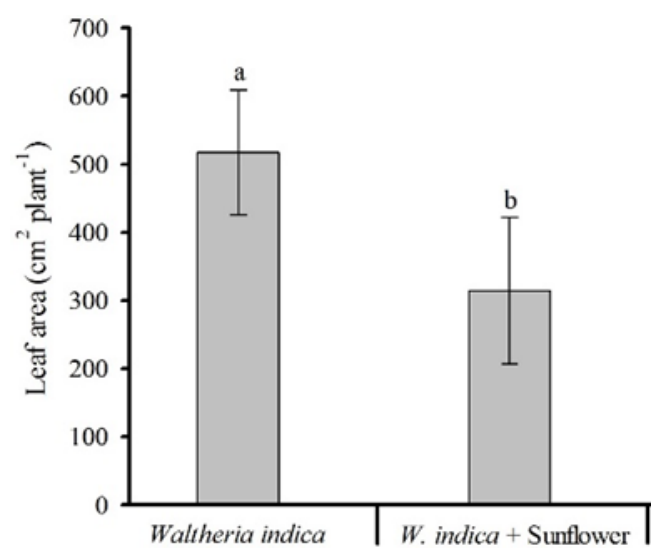

Figure 3. Waltheria indica leaf area as a function of competition with sunflower. Means followed by the same letter do not differ at the $5 \%$ probability level by the Tukey's test. Error bars indicate the mean confidence interval at $95 \%$ probability.

The water deficit regime did not reduce the dry mass of $W$. indica, except for the DLM (Figure 4A). This could be related to the fact that $W$. indica is a species with an investing mechanism in response to water deficiency, i.e., it maintains root water absorption and photosynthetic activity as the soil plants, thus competing for available water with the crop and producing a higher DRM than that of the crop.

The lower development of the root system of the crop in the treatments with competition can result in less competitive plants by decreasing the capacity to absorb water and nutrients (ZANINE; SANTOS, 2004). In general, competition between crops and weeds is more severe when the root system, morphology, and growth habit of plants are similar (DASS et al., 2017).

\section{Effect of competition and water deficiency on weed growth}

For $W$ indica, interaction between competition factors and water regimes on DLM was observed. There was an isolated effect of water regimes on LA, DLM, DSM, DRM, and TDM; however, for ALT there was no significant effect, with a general mean of $46.16 \mathrm{~cm}^{\text {plant }}{ }^{-1}$. For $A$. spinosus, interaction was observed between the competition factors and water regimes for DLM and TDM. There was an isolated effect of competition and water regimes for DLM, DSM, DRM, and TDM. Conversely, a single effect of the competition factor was observed for FA, whereas for ALT no significant effect was observed, with a general mean of 65.12 plant $^{-1}$.

Regarding LA of $W$. indica (Figure 3), the weeds that were in coexistence with the sunflower crop had lower mean values than that of the weeds in the treatment without competition. dries to the detriment of its water state (OLIVEIRA et al., 2018). The reduction in DLM might be due to a decrease in leaf thickness, a strategy that maximizes transpiration, and thus increases the capacity of the plant to absorb soil water in more negative potentials (FANG; XIONG, 2015). 

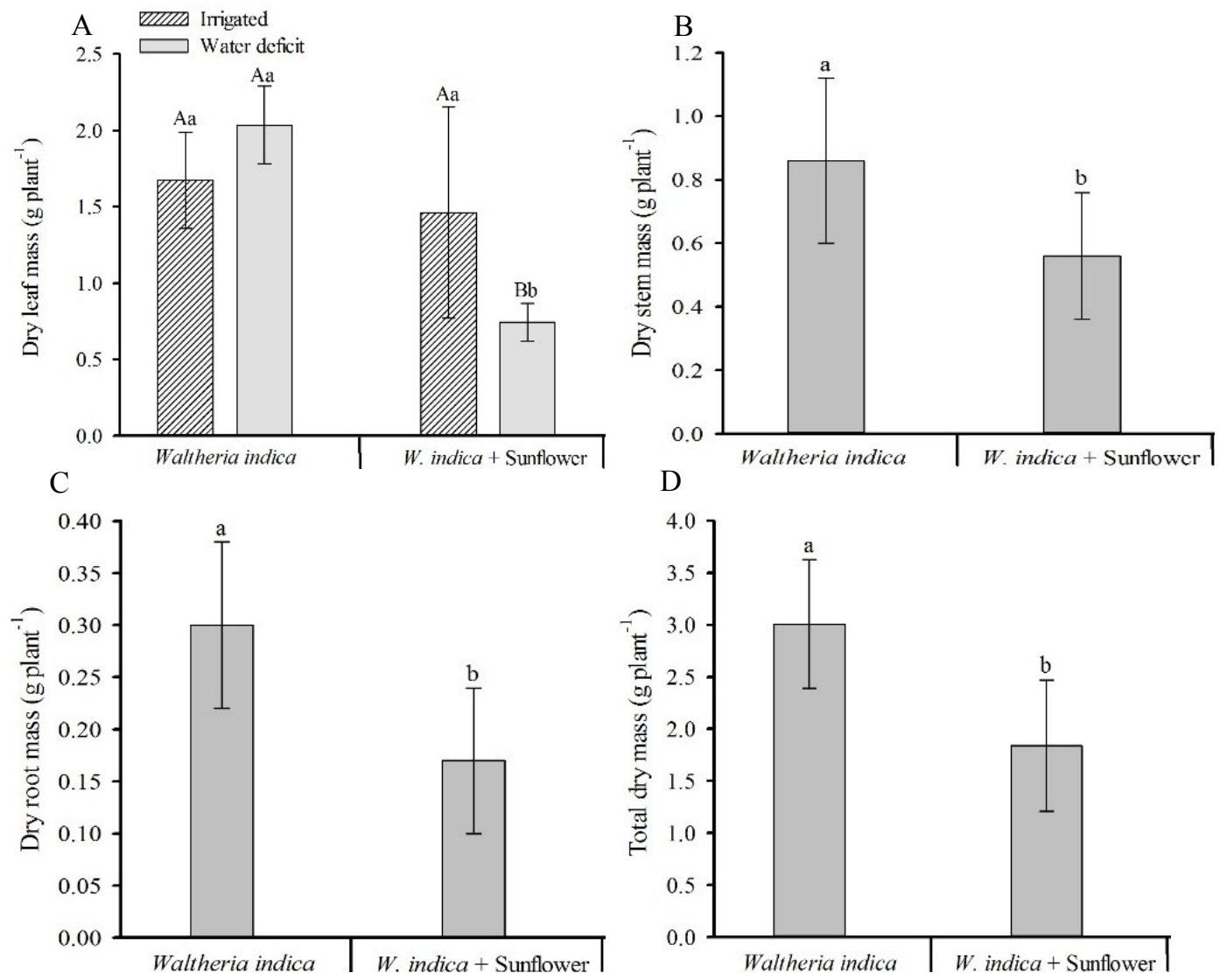

Figure 4. Dry leaf mass (A), dry stem mass (B), dry root mass (C), and total dry mass (D) of Waltheria indica as a function of water regimes and competition with sunflower. Figure 4A: means followed by the same lowercase letter (between the competition arrangements in each water regime) and upper case (between the water regimes within each competition arrangement) do not differ at the 5\% probability level by the Tukey's test. Other figures: means followed by the same letter do not differ at the level of 5\% of probability by the Tukey's test. Error bars indicate the mean confidence interval at $95 \%$ probability.

For DLM of $W$. indica (Figure 4A), competition with sunflower plants produced values that were $63.7 \%$ lower under the water deficit regime than that of the treatment without competition. Lower means of DSM (Figure 4B), DRM (Figure 4C), and TDM (Figure 4D) were found in $W$. indica weeds that grew together with the crop.

Similar to $W$. indica, competition had an isolated negative effect on the AF of the A. spinosus weeds (Figure 5), with $37.4 \%$ lower values than that of the treatment without coexistence.

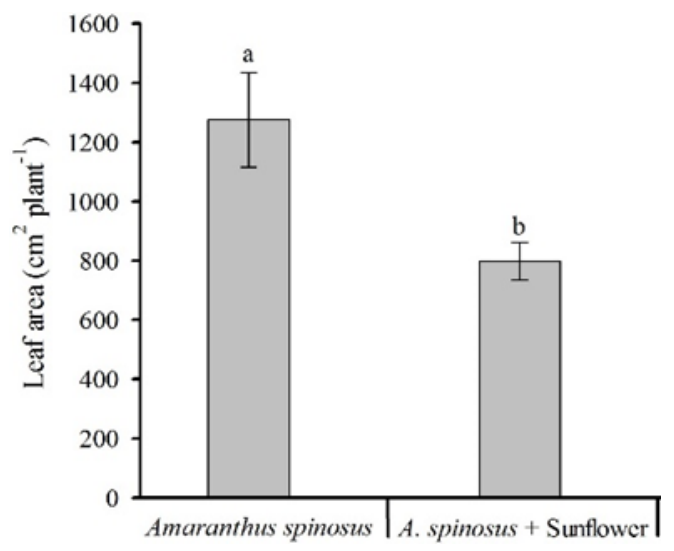

Figure 5. Amaranthus spinosus leaf area as a function of the competition effect with sunflower. Means followed by the same letter do not differ at the 5\% probability level by the Tukey's test. Error bars indicate the mean confidence interval at $95 \%$ probability. 
The water deficit regime negatively influenced the DLM, DSM, DRM, and TDM of $A$. spinosus weeds, with losses of approximately $22.3 \%$, $17.5 \%, 19.2 \%$, and $22.7 \%$, respectively, compared to the irrigated treatment (Figure 6).

The reduction in dry mass for $A$. spinosus weeds under a water deficit regime can be justified by the inhibition of cell expansion. This occurs due to the reduction of turgescence in plant cells (cell dehydration) under water deficiency (DODD;
RYAN, 2016). Under conditions of water restriction, Amaranthus plants can suspend transpiration by reducing the stomatal opening, which saves the water supply in the plant for a longer period (ASSAD et al., 2017). This mechanism of adaptation allows the plant to survive; however, its yield is compromised (TAIZ et al., 2017). For example, in A. cruentus plants, biomass was reduced by $50 \%$ under a water deficit regime (MLAKAR et al., 2012).
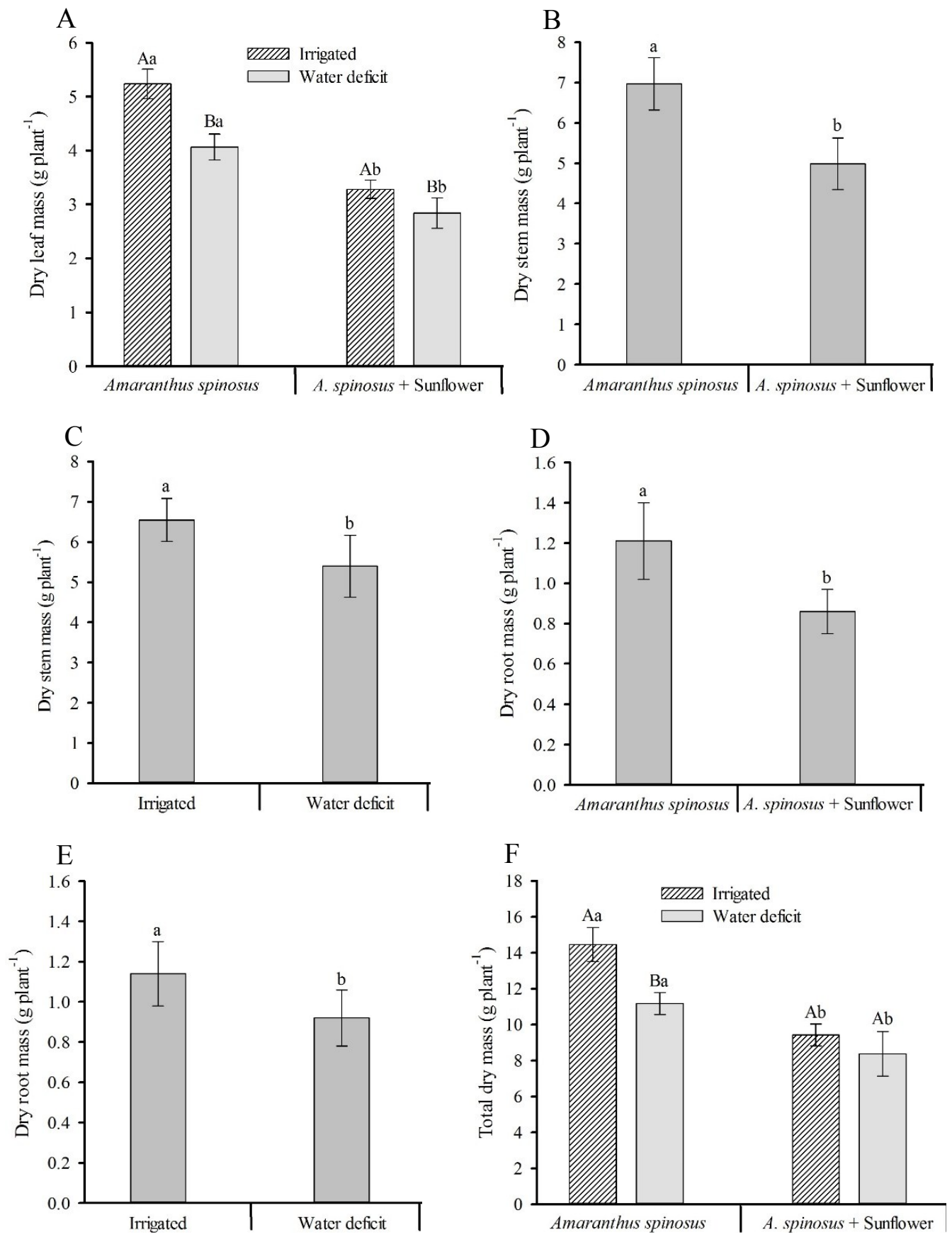

Figure 6. Dry leaf mass (A), dry stem mass (B, C), dry root mass (D, E), and total dry mass (F) of Amaranthus spinosus as a function of water regimes and competition with sunflower. Figure $6 \mathrm{~A}$ and $6 \mathrm{~F}$ : means followed by the same lowercase letter (between the competition arrangements in each water regime) and upper case (between the water regimes within each competition arrangement) do not differ at the 5\% probability level by the Tukey's test. Other figures: means followed by the same letter do not differ at the level of 5\% of probability by the Tukey's test. Error bars indicate mean confidence interval at $95 \%$ probability. 
Competition with the sunflower crop reduced the DLM, DSM, DRM, and TDM of A. spinosus weeds (Figure 6). A similar reduction was found in a study by Qasem (2018) who evaluated the competition of $A$. retroflexus with tomato cultivars. This author verified a lower dry mass of $A$. retroflexus when in coexistence with the crop. In terms of DLM and TDM, competition intensified the negative effects of water deficiency, resulting in lower values, with 2.84 and $8.37 \mathrm{~g}$ plant $^{-1}$, respectively.

Therefore, competition reduced the growth of both species (crop and weeds), indicating competition for the same resources (FRANCO et al., 2017). In most cases, the crop may have a greater competitive ability than the weed alone because the weed effect is not caused by its individual competitive capacity, but rather by the total population of the weed community (VILÀ; WILLIAMSON; LONSDALE, 2004). Reductions in weed growth components have also been found in Eleusine indica in association with soybean crops (FRANCO et al., 2017) and in Commelina benghalensis and $W$. indica in coexistence with cowpeas (OLIVEIRA et al., 2018).

$W$. indica and $A$. spinosus showed different behaviors under water deficient conditions and under competitive conditions with the sunflower crop. Some of these growth differences between species can be attributed to different water absorption capacities and mechanisms of adaptation to water deficit conditions (CHAVES, 2002).

The combined effect of competition with $W$. indica and $A$. spinosus weeds and the stress caused by water deficiency impaired sunflower growth. Thus, it is important to adopt control measures of these weeds during the early stages of crop production to avoid competition and save the available water in the soil for the cultivated plants.

\section{CONCLUSIONS}

Interspecific competition reduced the growth of sunflower plants, and Waltheria indica and Amaranthus spinosus weeds.

Waltheria indica and Amaranthus spinosus aggravated the negative effects of water deficiency on sunflower growth.

Water deficiency did not affect the growth of Waltheria indica.

$A$. spinosus was more competitive with the sunflower than was $W$. indica.

\section{REFERENCES}

ABELES, F. B.; MORGAN, P. W.; SALTVEIT JR, M. E. Ethylene in plant biology. 2. ed. San Diego,
CA: Academic press, 1992. 414 p.

AHMAD, R. et al. Does nitrogen fertilization enhance drought tolerance in sunflower? A review. Journal of plant nutrition, v. 37, n. 6, p. 942-963, 2014.

ALMEIDA, M. O. et al. Interação entre volume de vaso e competição com plantas daninhas sobre o crescimento da soja. Revista Ceres, v. 62, n. 6, p. 507-513, 2015.

ALVES, G. S. et al. Períodos de interferência das plantas daninhas na cultura do girassol em Rondônia. Revista Brasileira de Engenharia Agrícola e Ambiental, v. 17, n. 3, p. 275-282, 2013.

ASSAD, R. et al. Biology of Amaranths. The Botanical Review, v. 83, n. 4, p. 382-436, 2017.

BHATT, R. M.; SRINIVASA RAO, N. K. Influence of pod load on response of okra to water stress. Indian Journal of Plant Physiology, v. 10, n. 1, p. $54,2005$.

CASTRO, C.; LEITE, R. M. V. B. C. Main aspects of sunflower production in Brazil. Oilseeds \& fats Crops and Lipids, v. 15, n. 2, p. 1-11, 2018.

CHAUHAN, B. S.; ABUGHO, S. B. Effect of water stress on the growth and development of Amaranthus spinosus, Leptochloa chinensis, and rice. American Journal of Plant Sciences, v. 4, n. 5, p. 989-998, 2013.

CHAVES, M. M. How plants cope with water stress in the field? Photosynthesis and growth. Annals of Botany, v. 89, n. 7, p. 907-916, 2002.

CORRE-HELLOU, G. et al. The competitive ability of pea-barley intercrops against weeds and the interactions with crop productivity and soil N availability. Field Crops Research, v. 122, n. 3, p. 264-272, 2011.

DAN, H. A. et al. Desempenho de plantas sorgo granífero sobre condições de sombreamento. Acta Scientiarum Agronomy, v. 32, n. 4, p. 675-679, 2010

DANTAS, M. S. M. et al. Production and morphological components of sunflower on soil fertilized with cassava wastewater. Revista Ceres, v. 64, n. 1, p. $77-82,2017$.

DASS, A. et al. Weed management in rice using crop competition-a review. Crop Protection, v. 95, n. 6 , p. 45-52, 2017.

DÍAZ-LÓPEZ, L. et al. Jatropha curcas seedlings 
show a water conservation strategy under drought conditions based on decreasing leaf growth and stomatal conductance. Agricultural Water Management, v. 105, n. 5, p. 48-56, 2012.

DODD, I. C.; RYAN, A. C. Whole-plant physiological responses to water-deficit stress. 2 . ed. Chichester, UK: ELS, 2016. 9 p.

ELEZOVIC, I. et al. Yield and yield components of imidazolinone-resistant sunflower (Helianthus annuus L.) are influenced by pre-emergence herbicide and time of post-emergence weed removal. Field Crops Research, v. 128, n. 3, p. 137-146, 2012.

EMPRESA BRASILEIRA DE PESQUISA AGROPECUÁRIA - EMBRAPA. Sistema brasileiro de classificação de solos. 3 ed. rev. ampl. Brasília, DF: Embrapa, 2013. 353 p.

FANG, Y.; XIONG, L. General mechanisms of drought response and their application in drought resistance improvement in plants. Cellular and Molecular Life Sciences, v. 72, n. 4, p. 673-689, 2015.

FOOD AND AGRICULTURE ORGANIZATION OF THE UNITED NATIONS - FAO. FAOSTAT. Production, Crops Sunflower seed. 2016. Disponível em: <http://www.fao.org/faostat/en/ \#data/QC>. Acesso em: 28 fev. 2018.

FRANKLIN, K. A. Photomorphogenesis: Plants feel blue in the shade. Current Biology, v. 26, n. 24, p. 1275-1276, 2016.

FERREIRA, D. F. Sisvar: A computer statistical analysis system. Ciência e Agrotecnologia, v. 35, n. 6, p. 1039-1042, 2011.

FRANCO, J. J. et al. Competitividade relativa de biótipos de capim pé-de-galinha com a cultura da soja. Revista Caatinga, v. 30, n. 2, p. 271-277, 2017.

GOMMERS, C. M. M. et al. Shade tolerance: when growing tall is not an option. Trends in Plant Science, v. 18, n. 2, p. 65-71, 2013

JALEEL, C. A. et al. Drought stress in plants: a review on morphological characteristics and pigments composition. International Journal of Agriculture \& Biology, v. 11, n. 1, p. 100-105, 2009.

KILLI, D. et al. Adaptation to high temperature mitigates the impact of water deficit during combined heat and drought stress in C3 sunflower and $\mathrm{C} 4$ maize varieties with contrasting drought tolerance. Physiologia Plantarum, v. 159, n. 2, p. 130-147, 2017.

LAGE, P. et al. Interferência do arranjo de plantas daninhas no crescimento do feijoeiro. Revista de Agricultura Neotropical, v. 4, n. 3, p. 61-68, 2017.

LIMA, M. F. P. et al. Weed growth and dry matter partition under water restriction. Planta Daninha, v. 34 , n. 4, p. 701-707, 2016.

LOBELL, D. B. et al. The shifting influence of drought and heat stress for crops in northeast Australia. Global Change Biology, v. 21, n. 11, p. $4115-4127,2015$.

LU, P. et al. Different growth responses of an invasive weed and a native crop to nitrogen pulse and competition. Plos One, v. 11, n. 6, p. 1-13, 2016.

MLAKAR, S. G. et al. The effect of drought occurring at different growth stages on productivity of grain amaranth Amaranthus cruentus G6. Journal of Life Sciences, v. 6, n. 3, p. 283-286, 2012.

OLIVEIRA, F. S. et al. Competition between cowpea and weeds for water: Effect on plants growth. Revista Brasileira de Ciências Agrárias, v. 13, n. 1, p. $1-7,2018$

QASEM, J. R. Competition of redroot pigweed (Amaranthus retroflexus L.) and nettle-leaved goosefoot (Chenopodium murale L.) with tomato (Lycopersicon esculentum Mill.) cultivars. The Journal of Horticultural Science and Biotechnology, v. 93, n. 3, p. 1-10, 2018.

RAHMATI, M. et al. Disentangling the Effects of Water Stress on Carbon Acquisition, Vegetative Growth, and Fruit Quality of Peach Trees by Means of the QualiTree Model. Frontiers in Plant Science, v. 9 , n. 10 , p. 1-16, 2018.

RIBEIRO, A. C; GUIMARÃES, P. T. G.; ALVAREZ, V. H. V. Recomendações para uso de corretivos e fertilizantes em Minas Gerais: $5^{\text {a }}$ Aproximação. 1. ed. Viçosa, MG: CFSEMG, 1999. 359 p.

SILVA, R. R. et al. Períodos de interferência de plantas daninhas na cultura do girassol. Bragantia, v. 72, n. 3 , p. $255-261,2013$

SOUSA, C. C. M. et al. Crescimento e respostas enzimáticas do feijoeiro caupi sob estresse hídrico e nematoide de galhas. Revista Brasileira de Engenharia Agrícola e Ambiental, v. 19, n. 2, p. 113-118, 2015.

SOUZA, M. S. et al. Comparação de métodos de 
mensuração de área foliar para a cultura da melancia. Pesquisa Agropecuária Tropical, v. 42, n. 2, p. 241 $-245,2012$.

SZYMEZAK, L. S. et al. Habilidade competitiva de capim aries com plantas daninhas no estabelecimento: características morfológicas. Revista Ciência Agronômica, v. 47, n. 3, p. 471480, 2016.

TAIZ, L. et al. Fisiologia e desenvolvimento vegetal: transporte e translocação de água e solutos. 6. ed. Porto Alegre, RS: ARTMED, 2017. 888 p.

URBAN, L.; AARROUF, J.; BIDEL, L. P. R. Assessing the effects of water deficit on photosynthesis using parameters derived from measurements of leaf gas exchange and of chlorophyll a fluorescence. Frontiers in Plant Science, v. 8, n. 2, p. 1-18, 2017.

VILÀ, M.; WILLIAMSON, M.; LONSDALE, M. Competition experiments on alien weeds with crops: lessons for measuring plant invasion impact? Biological Invasions, v. 6, n. 1, p. 59-69, 2004.

ZANINE, A. M.; SANTOS, E. D. Competição entre espécies de plantas - uma revisão. Revista da Faculdade de Medicina Veterinária e Zootecnia da Universidade de São Paulo, v. 11, n. 1, p. 103$122,2004$. 